\title{
Swissness Communication and its Impact on Consumer-Brand Relationships
}
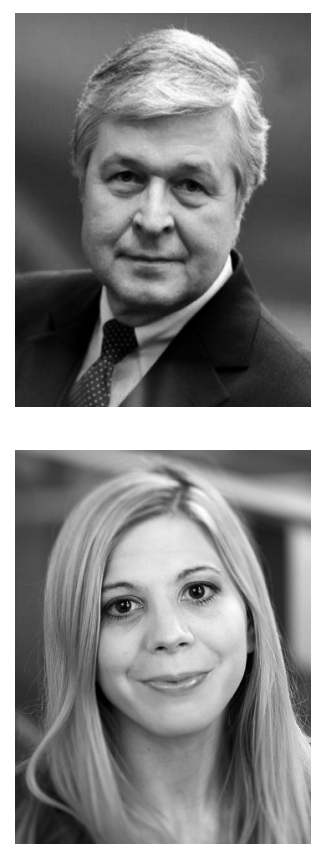

Manfred Brubn \& Verena Batt

Brand Commitment, Brand Loyalty, Brand Trust, Consumer-Brand Relationships, Country-of-Origin, Swissness Communication.

Markencommitment, Markenloyalität, Markenvertrauen, MarkenKonsumenten-Beziehungen, Country-of-Origin, Swissnesskommunikation.

While the topic of country-of-origin has received widespread attention in literature, the focus has been primarily on product quality and purchase intentions. Less research has been conducted on the effects of country-of-origin in the context of consumer relationships. The present paper addresses this research gap. For this purpose, the concept of 'Swissness Communication' and its influence on consumer-brand relationships is investigated. The developed model is empirically tested by surveying 976 German consumers. The findings reveal that the Swissness Communication construct consists of three factors: high performance quality, exclusivity, and sympathy. Furthermore, the results disclose that Swissness Communication has the potential to build strong consumer-brand relationships.

Die Marketingliteratur hat sich mit dem Thema Country-of-Origin bereits ausführlich beschäftigt. Der Fokus lag hierbei jedoch primär auf der Wirkung des Country-of-Origin auf die Grössen Produktqualität und Kaufabsicht. Die Untersuchung von Country-of-OriginEffekten in Bezug auf Marken-Konsumenten-Beziehungen wurde bislang weitgehend vernachlässigt. Der vorliegende Beitrag nimmt sich dieser Forschungslücke an. Das Ziel ist es, das Konstrukt "Swissness Communication" und seine Wirkung auf Marken-Konsumenten-Beziehungen zu untersuchen. Für die empirische Überprüfung des entwickelten Untersuchungsmodells werden 976 Konsumenten aus Deutschland befragt. Die Ergebnisse zeigen, dass das Konstrukt Swissness Communication aus drei Dimensionen besteht: hohe Leistungsqualität, Exklusivität und Sympathie. Darüber hinaus wird das Potenzial der Swissness Communication zum Aufbau starker Marken-Konsumenten-Beziehungen deutlich.

\section{Introduction}

In marketing, country-of-origin (COO) has been identified as an important factor in the consumer decision-making process. Consumers refer to the COO label particularly in purchase situations when they have insufficient information in order to make easy comparisons or evaluations (Thorelli et al. 1989). COO is primarily used as a substitute for miss- 
ing quality information and performance features when comparing foreign products (Parameswaran/Pisharodi 1994). In other words, COO provides an assurance of the product's or service's quality and reduces risks for the consumer (Cordell 1992). With the increasing internationalization of corporate activity, a COO label presents an important competitive advantage. Companies distinguish their brands from the competition by linking the COO concept to brand associations (Balabanis/Diamantopoulos 2011).

Since Schooler's (1965) article which introduced the COO phenomenon, research on the topic of $\mathrm{COO}$ has been very extensive (see, for example, the literature review by Bilkey and Nes (1982) and the meta-analysis of Verlegh and Steenkamp (1999)). The main focus of these research contributions was primarily on product evaluation (e.g., Gürhan-Canli/ Maheswaran 2000; Lee/Lee 2009; Cilingir/Basfirinci 2014) as well as on the influence of COO on purchase intention (e.g., Hong/Kang 2006; Usunier/Cestre 2007; Balabanis/ Diamantopoulos 2011; Unahanandh/Assarut 2013). For example, COO has been found to positively influence customers' perceptions of the quality and desirability of a product (e.g., Hastak/Hong 1991; Piron 2000; Veale/Quester 2009). Furthermore, numerous studies indicate that the importance of $\mathrm{COO}$ on consumers depends on market and productspecific circumstances (e.g., high vs. low status items) (Quester/Smart 1998) and on consumer characteristics (e.g., mood) (Maheswaran/Chen 2006).

Despite the large number of studies conducted on COO, it is striking that the focus of most research has been on cognitive- and behaviour-related effects, e.g., on product quality or purchase intention, as mentioned above. Less research has been conducted on the affective-related effects of COO (e.g., Jiménez/San Martín 2010). However, as countries evoke strong symbolic and emotional connotations, $\mathrm{COO}$ is not only associated with the signaling of product quality, but also relates to affective associations such as emotions, autobiographical memories, or identity (Verlegh/Steenkamp 1999). Hence, COO is able to positively influence affective-related variables such as consumers' product or brand attitudes, or consumer-brand relationships (Verlegh/Steenkamp 1999; Swaminathan et al. 2007). A positive effect of $\mathrm{COO}$ on brand attitudes has been reported in several studies (e.g., Verlegh et al. 2005; Swaminathan et al. 2007; Lee et al. 2013). However, the COO's influence on consumer-brand relationships has been widely neglected so far. Strong consumer-brand relationships lead to higher brand loyalty, a lower price susceptibility, and greater sales (Chang/Chieng 2006). Thus, building strong consumer-brand relationships is of particular relevance for companies.

The purpose of this paper is to close this research gap by studying the impact of communicated $\mathrm{COO}$ on consumer-brand relationships. We consider Switzerland with regard to the COO effect. Although numerous Swiss companies employ the concept of 'Swissness' as a 'seal of approval' in their communication activities, only a handful of researchers have addressed Switzerland in their studies on COO (e.g., Li/Wyer Jr. 1994; Kühn/Weiss 1998; Brubn et al. 2012; Feige et al. 2013). Given the mentioned importance of building strong consumer-brand relationships, it is important that Swiss companies understand the role that $\mathrm{COO}$ can provide here. The present paper takes a step towards understanding the effect of $\mathrm{COO}$ on consumer-brand relationships with regard to Swiss brands. Specifically, we address the question of how 'Swissness Communication', that is, the perceived degree to which the Swiss origin of brands is communicated to consumers, has an influence on the relationship between consumers and brands. On the one hand, the findings provide insights into the potential that $\mathrm{COO}$ communication offers in building 
strong consumer-brand relationships. On the other hand, the study provides important implications for Swiss companies which seek to engage customers in long-term relationships.

The remainder of this paper is organized as follows: We begin by defining the concept of Swissness Communication. Then, we develop the conceptual model of Swissness Communication and its influence on consumer-brand relationships. Drawing on the work of Morgan and Hunt (1994), we consider brand commitment and brand trust as variables reflecting strong consumer-brand relationships. Furthermore, we include brand loyalty in our model. The latter construct is chosen, because, on the one hand, brand loyalty is linked to diverse marketing advantages such as increased market share (Chaudhuri/ Holbrook 2001). On the other hand, research has shown that brand loyalty is a main consequence of consumer-brand relationships (Kressmann et al. 2006; Smit et al. 2007). Then, we empirically test the proposed model using data obtained through an online survey of German consumers. We present the measures and results of the study and discuss the findings in terms of their managerial relevance. Finally, we offer directions for further research.

\section{Swissness Communication}

As already mentioned, Swissness Communication can be defined as the perceived degree to which the Swiss origin of brands is communicated to consumers. In other words, Swissness communication is understood as the perceived extent to which typical characteristics of Switzerland and its products or services are communicated. However, a conceptualization and scale for measuring Swissness Communication has not been developed so far. For this reason, a conceptual development of the concept is needed.

To identify the facets of the construct, we reviewed literature dealing with Swissness as a COO concept and its characteristics (Feige et al. 2013). Furthermore, we conducted 25 qualitative interviews with consumers in order to examine whether the findings from the literature review were in line with consumers' mental associations with Swissness. The work of Feige et al. (2013) is based on a representative study which surveys 13,320 consumers from 14 countries (e.g., Switzerland, Germany, India, China, USA, Spain). The survey participants had to indicate their mental associations with Switzerland. In sum, five characteristics of Switzerland emerged. First, Switzerland is perceived as a country with a high quality of life. Second, Switzerland is associated with a high degree of reliability. Third, hospitality is seen to be a characteristic of Switzerland. Furthermore, another characteristic of Switzerland is its beautiful landscape. Finally, Switzerland is linked with sympathy. In addition, the authors asked the survey participants to name their associations with Swiss products and services. In summary, the respondents reported the following characteristic associations: high performance quality, exclusivity, traditional/-ism, reliability, and environmental friendliness.

After that, we conducted qualitative interviews with German consumers. The interviews lasted 30-45 minutes. German consumers were chosen because the later quantitative study was also targeted at Germans. Moreover, Germans seemed to be familiar with the characteristics of Switzerland. We asked participants about their mental associations with Swiss products and services. In order to simplify our question, we gave them the possibility to name Swiss brands they have positive associations with. We put the focus on positive associations, because we assume that negative characteristics would not be conducive to pro- 
moting Swiss products and services or to building strong consumer-brand relationships. After naming Swiss brands, respondents had to describe in an open-ended way what comes to mind when thinking about these brands. The following characteristics of Swiss products and services emerged: high performance quality, exclusivity, sympathy, reliability, and naturalness.

In sum, we collected 10 characteristics of Switzerland and Swiss products and services which can be used to communicate the Swiss origin of brands to consumers: high quality of life, reliability, hospitality, beautiful landscape, sympathy, high performance quality, exclusivity, traditional/-ism, naturalness, environmental friendliness, and naturalness. It is striking to observe that some of the associations are identified both on the basis of the literature research and on the basis of the interviews (high performance quality, exclusivity, reliability, and sympathy). Furthermore, in view of the large number of characteristics, Swissness Communication should be conceptualized as a multidimensional construct.

\section{Model Development}

\subsection{Impact of Swissness Communication on Consumer-Brand Relationships}

As already mentioned, brand commitment and brand trust are considered as indicators of strong consumer-brand relationships. For this reason, both variables are included in our research model.

Brand commitment implies an emotional attachment of a consumer to a brand (Tuskej et al. 2013). It is grounded in the consumer's identification with the brand and in values that are shared between consumers and the brand (Albert et al. 2013). The importance of commitment for building and maintaining long-term brand-consumer relationships, similar to close human relationships, arises from a psychological sense of well-being that an intimate, emotional brand relationship can offer the consumer. Close relationships give the relationship partners a sense of emotional security and stability (Chaudhuri/Holbrook 2002).

According to social identity theory, people derive traits of their personality from their membership of social groups. These elements of personality form an individual's social identity (Tajfel/Turner 1985). People who adore and/or purchase the same brand form social groups. Once they have gained membership of an attractive brand, people start to derive personality traits from their membership of the brand (Dutton et al. 1994). By communicating a brand's Swiss origin, it is possible to generate a positive, distinctive identity for the brand (see the positive characteristics associated with Switzerland and its products and services discussed in Chapter 2). Thus, by increasing the degree of Swissness Communication, a brand can increase its attractiveness. Consequently, Swissness Communication can be used to enhance a brand's positive personality traits so that people will develop a strong sense of belonging to the brand and, thereby, also identify with it. These reflections result in the following hypothesis:

\section{H1: Swissness Communication has a positive effect on brand commitment.}

Drawing on Chaudhuri and Holbrook (2001, p. 82), we define brand trust as "the willingness of the average consumer to rely on the ability of the brand to perform its stated function". Brand trust is primarily the result of reducing the level of complexity and uncertainty associated with the brand (Casalo et al. 2008). For example, consumers who rely 
on perceived brand features are able to reduce the level of their perceived purchase risk as well as the cost and effort associated with a purchase. Hence, brand trust is linked to consumers' expectations about the reliability of the brand in a risky situation (Mazodier/ Merunka 2012). As long as consumers' expectations are fulfilled by a brand, trust and, hence, the relationship to the brand will both be reinforced (Walter et al. 2003).

Drawing on signaling theory (Spence 1973), we assume that Swissness Communication has a positive influence on brand trust. Extrinsic cues have an impact on consumers' brand expectations (Mazodier/Merunka 2012). The communication of the Swiss origin of a brand represents an extrinsic cue and, therefore, evokes inferences with regard to the brand's ability to fulfil consumers' expectations about its reliability. In the literature review and in our interviews, it has been shown that Switzerland, and Swiss products and services are linked to positive characteristics such as high performance quality or exclusivity (see Chapter 2). Hence, the communication of the brand's Swiss origin might signal these positive characteristics to the customer and, thereby, enhance the trustworthiness of the brand. It thus follows that:

\section{H2: Swissness Communication has a positive effect on brand trust.}

\subsection{Impact of Consumer-Brand Relationships on Brand Loyalty}

Following Oliver (1999, p. 34), we define brand loyalty as "a deeply held commitment to rebuy or repatronize a preferred product/service consistently in the future, thereby causing repetitive same-brand or same brand-set purchasing, despite situational influences and marketing efforts having the potential to cause switching behavior". Brand loyalty implies behaviours such as repurchase intention, positive word-of-mouth, willingness to pay a price premium, or cross-selling behaviour.

As mentioned earlier, people derive traits of their personality from being a part of an attractive brand. Therefore, a brand which is no longer successful in the market will fail to elicit a positive social identity in its consumers. Consequently, according to social identity theory, people who highly identify with a brand will want it to be successful. Thus, they support the brand by displaying loyalty in order to preserve their own social identity (Dutton et al. 1994). We therefore posit:

\section{H3: Brand commitment has a positive effect on brand loyalty.}

Delgado-Ballester and Munuera-Alemán (2001, p. 1240) posit that brand trust is a "[...] key variable in the development of an enduring desire to maintain a relationship in the long term, for example with a brand". Hence, brand trust is associated with brand loyalty. This assumption is confirmed by the literature. Brand trust is a well-established antecedent of brand loyalty (e.g., Sirgy et al. 1991; Morgan/Hunt 1994; Mazodier/Merunka 2012). Thus, we posit:

H4: Brand trust has a positive effect on brand loyalty.

Figure 1 depicts the proposed model. 


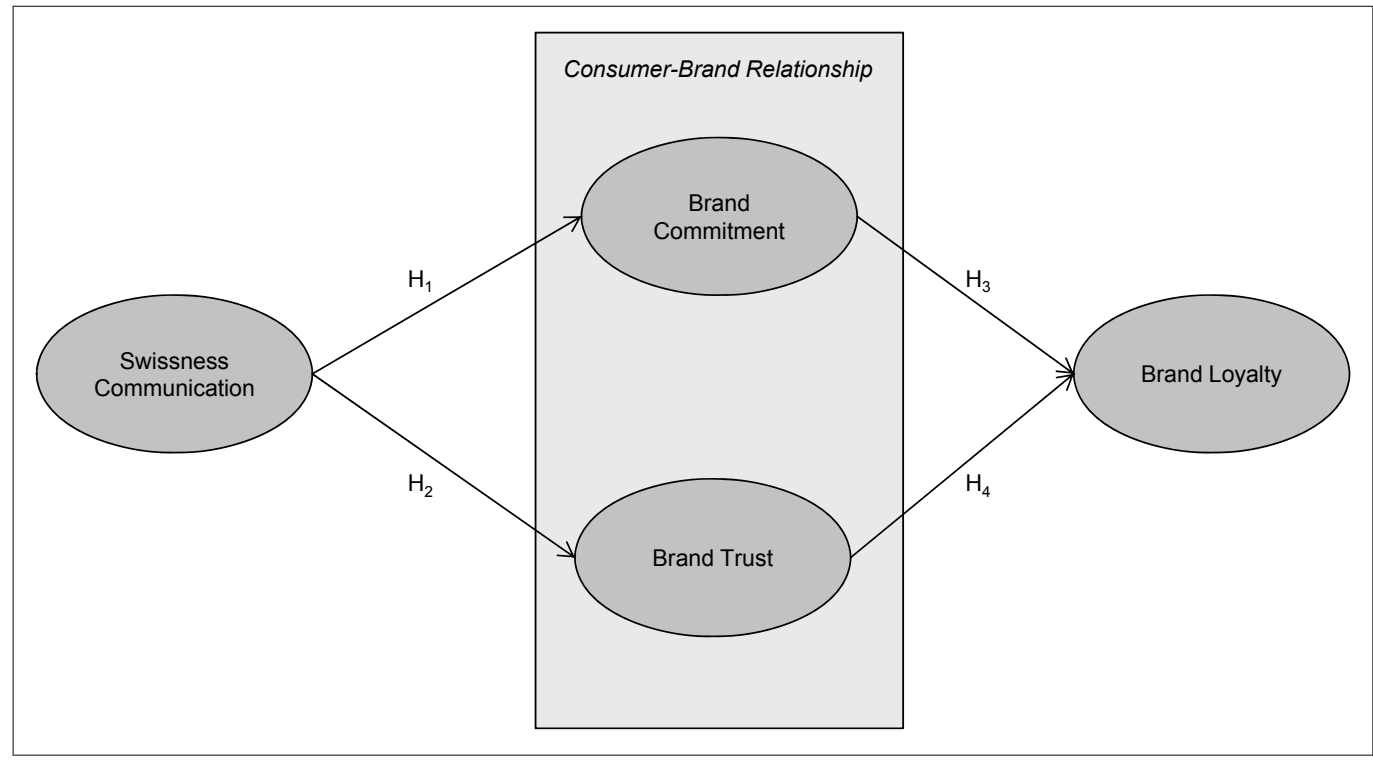

Figure 1: Research model

\section{Methodology}

\subsection{Sample}

To test the developed research model, data was obtained by surveying German consumers. The merit of selecting 'non-Swiss' participants for the survey is justified because doing so avoids a potential under-estimation of the COO effect. Four Swiss brands (Ricola, Swiss International Air Lines, Swatch and Credit Suisse) were selected as suitable representatives of the Swiss consumption and service sector. The participants had to answer the questionnaire with regard to one of the four brands. All of these four brands are highly recognized internationally as representing typical elements of Swissness.

Invitations to participate in the study were emailed to 11,000 individuals. With a response rate of 23.21 percent, 2,554 individuals participated in the survey. Not completed datasets were eliminated from the sample. A total of 976 questionnaires were included in the study. We attempted to achieve an almost equal sample size for each brand. With regard to the breakdown by gender, the data set contained 67.4 percent male and 32.6 percent female responses. Of the total, 22 percent of the survey participants were 40 years of age or younger, 45.5 percent were between 40 and 60 years of age, and 32.5 percent were 60 years of age or older.

\subsection{Measurement and Validation of Constructs}

\section{Swissness Commmunication}

To measure Swissness Communication, we developed an item battery for the 10 identified dimensions consisting of three items per dimension. Because our study is the first to explore the dimensions quantitatively, we could not draw on established scales in the literature. Thus, we were obliged to create new scales. The questions were related to advertising 
as the latter represents a specific and often used instrument for communicating the Swiss origin of the considered brands. The dimensions were measured using a seven-point Likert scale and were operationalized reflectively. Respondents were asked to indicate their level of agreement with each statement.

We began with an exploratory factor analysis of the 30 items using principal component analysis and a Varimax rotation in SPSS 21. We eliminated items with factor loadings smaller than 0.7 or cross loadings greater than 0.4 . This resulted in a three-factor solution containing the factors high performance quality, exclusivity, and sympathy. Hence, Swissness Communication is represented by these dimensions.

Next, we conducted a confirmatory factor analysis (CFA) to evaluate reliability and convergent and discriminant validity. Factor loadings are 0.92 and higher. Cronbach's alpha $(\alpha)$ values for each dimension were calculated and deemed acceptable (values of 0.95 and higher). The values for composite reliability (CR) are each 0.96 and therefore exceed the relevant threshold value that is recommended in the literature (Bagozzi/Yi 1988; Fornell/Larcker 1981). Furthermore, the analysis shows that the average variance extracted (AVE) for all the constructs exceeds the threshold of 0.50 ; the lowest value is 0.83 (see Table 1$)$. The model also shows a satisfactory fit with the data $(\chi 2 / \mathrm{df}=9.35, \mathrm{CFI}=0.98$, TLI $=0.98$, RMSEA $=0.09$, SRMR $=.03$ ). Finally, we tested for discriminant validity on the basis of the criteria that Fornell and Larcker (1981) suggest. The results did not show any violation. Hence, discriminant validity is given (see Table 2 ).

\begin{tabular}{|c|c|c|c|c|c|}
\hline Variable & Items & $\begin{array}{c}\text { Factor } \\
\text { loadings } \\
\text { (CFA) }\end{array}$ & $\begin{array}{c}\text { Cronbach`s } \\
\alpha\end{array}$ & $\begin{array}{l}\text { Composite } \\
\text { Reliability } \\
\text { (CR) }\end{array}$ & $\begin{array}{c}\text { Average } \\
\text { Variance } \\
\text { Extracted } \\
(\text { AVE) }\end{array}$ \\
\hline $\begin{array}{l}\text { High Per- } \\
\text { formance } \\
\text { Quality }\end{array}$ & $\begin{array}{l}\text { - This brand's advertising [BRAND] } \\
\text { communicates the high performance } \\
\text { quality of Swiss products/services to } \\
\text { me. } \\
\text { - This brand's advertising [BRAND] } \\
\text { makes me aware of the reliability of } \\
\text { Swiss products/services. } \\
\text { - This brand's advertising [BRAND] } \\
\text { shows me that I can rely on Swiss } \\
\text { products/services. }\end{array}$ & 0.97 & 0.96 & 0.96 & 0.86 \\
\hline Exclusivity & $\begin{array}{l}\text { - This brand's advertising [BRAND] } \\
\text { reflects the exclusivity of Swiss } \\
\text { products/services. } \\
\text { - This brand's advertising [BRAND] } \\
\text { expresses the distinctiveness of } \\
\text { Swiss products/services. } \\
\text { - This brand's advertising [BRAND] } \\
\text { shows me that Swiss products/ } \\
\text { services are unique. }\end{array}$ & 0.95 & 0.95 & 0.96 & 0.83 \\
\hline
\end{tabular}




\begin{tabular}{|l|l|c|c|c|c|}
\hline Variable & Items & $\begin{array}{c}\text { Factor } \\
\text { loadings } \\
\text { (CFA) }\end{array}$ & $\begin{array}{c}\text { Cronbach`s } \\
\alpha\end{array}$ & $\begin{array}{c}\text { Composite } \\
\text { Reliability } \\
\text { (CR) }\end{array}$ & $\begin{array}{c}\text { Average } \\
\text { Variance } \\
\text { Extracted } \\
\text { (AVE) }\end{array}$ \\
\hline Sympathy & $\begin{array}{l}\text { - This brand's advertising [BRAND] } \\
\text { conveys a sympathetic impression of } \\
\text { Switzerland to me. } \\
\text { - This brand's advertising [BRAND] } \\
\text { conveys a friendly impression of } \\
\text { Switzerland to me. }\end{array}$ & 0.95 & 0.96 & 0.96 & 0.86 \\
$\begin{array}{l}\text { This brand's advertising [BRAND] } \\
\text { confirms my positive impression of } \\
\text { Switzerland. }\end{array}$ & 0.93 & & \\
\hline
\end{tabular}

Table 1: Measurement results for the construct of Swissness Communication

\begin{tabular}{|l|c|c|c|}
\hline & $\begin{array}{c}\text { High Performance } \\
\text { Quality }\end{array}$ & Exclusivity & Sympathy \\
\hline $\begin{array}{l}\text { High Perfor- } \\
\text { mance Quality }\end{array}$ & 0.86 & & 0.83 \\
\hline Exclusivity & 0.71 & 0.56 & 0.86 \\
\hline Sympathy & 0.63 & \multicolumn{2}{|c|}{0} \\
\hline $\begin{array}{l}\text { Note: Diagonal numbers in bold denote the average variance extracted (AVE). Numbers below the diag- } \\
\text { onal ones denote the degree of the squared correlations between the latent variables. }\end{array}$ \\
\hline
\end{tabular}

Table 2: Fornell/Larcker test for the Swissness Communication Dimensions

\section{Consumer-Brand Relationship and Brand Loyalty}

The four constructs of the model are measured using a seven-point Likert scale. The Swissness Communication construct was developed, as discussed above, in the current research paper. In order to reduce the complexity of the construct, we employed item-parcelling (Bagozzi/Heatherton 1994; Bagozzi/Edwards 1998), which resulted in one parcel for each factor. The construct of brand commitment was measured on the basis of Escalas and Bettman (2003). Our measure for brand trust was based on the scale of Delgado-Ballester et al. (2003) and adjusted to the context of the current study. The construct of brand loyalty was based on the scale of Brexendorf et al. (2010).

We conducted a confirmatory factor analysis (maximum likelihood method) to assess the psychometric properties of the measurements (Amos 7.0 and SPSS 21). All dependent and independent constructs were included in one multi-factorial confirmatory factor analysis model. The fit indices suggest that the model is a plausible representation of the structures underlying the empirical data. The factor loading for each item is 0.82 and higher. All Cronbach's alpha $(\alpha)$ values are greater than 0.86 (Nunnally/Bernstein 1994). The lowest CR is 0.88 , and the lowest AVE is 0.66 (see Table 3). This indicates good levels of reliability and convergent validity for the scales used. The Fornell/Larcker criterion is not fulfilled for each variable (see Table 4). For this reason, we additionally used the Chisquare difference test. The findings show that the Chi-square difference between the con- 
strained and the unconstrained model is always significant (see Table 5). Thus, discriminant validity is given.

\begin{tabular}{|c|c|c|c|c|c|}
\hline Variable & Items & $\begin{array}{l}\text { Factor } \\
\text { loadings } \\
\text { (CFA) }\end{array}$ & $\begin{array}{c}\text { Cronbach`s } \\
\alpha\end{array}$ & $\begin{array}{l}\text { Composite } \\
\text { Reliability } \\
\text { (CR) }\end{array}$ & $\begin{array}{c}\text { Average } \\
\text { Variance } \\
\text { Extracted } \\
\text { (AVE) }\end{array}$ \\
\hline $\begin{array}{l}\text { Swissness } \\
\text { Communi- } \\
\text { cation }\end{array}$ & $\begin{array}{l}\text { - High performance quality } \\
\text { (Item Parcelling) } \\
\text { - Exclusivity (Item Parcelling) } \\
\text { - Sympathy (Item Parcelling) }\end{array}$ & $\begin{array}{l}0.89 \\
0.89 \\
0.83\end{array}$ & 0.91 & 0.91 & 0.68 \\
\hline $\begin{array}{l}\text { Brand } \\
\text { Commit- } \\
\text { ment }\end{array}$ & $\begin{array}{l}\text { - I feel attached to this brand } \\
\text { [BRAND]. } \\
\text { - I can identify well with this brand } \\
\text { [BRAND]. } \\
\text { - This brand [BRAND] offers me } \\
\text { positive benefits. }\end{array}$ & $\begin{array}{l}0.95 \\
0.96 \\
0.86\end{array}$ & 0.94 & 0.95 & 0.80 \\
\hline $\begin{array}{l}\text { Brand } \\
\text { Trust }\end{array}$ & $\begin{array}{l}\text { - I feel confidence in [BRAND]. } \\
\text { - This brand [BRAND] has never } \\
\text { disappointed me. } \\
\text { - I am not anxious about what this } \\
\text { brand will do in future [BRAND]. }\end{array}$ & $\begin{array}{l}0.91 \\
0.82 \\
0.79\end{array}$ & 0.86 & 0.88 & 0.61 \\
\hline $\begin{array}{l}\text { Brand } \\
\text { Loyalty }\end{array}$ & $\begin{array}{l}\text { I will choose this brand [BRAND] } \\
\text { again in future. } \\
\text { - I will also try out / buy other prod- } \\
\text { ucts of this brand [BRAND]. } \\
\text { - I will recommend this brand } \\
\text { [BRAND] to other people. } \\
\text { - I intend to buy a product of this } \\
\text { brand [BRAND], even if it be- } \\
\text { comes more expensive. }\end{array}$ & $\begin{array}{l}0.94 \\
0.87 \\
0.93\end{array}$ & 0.94 & 0.94 & 0.66 \\
\hline
\end{tabular}

Table 3: Measurement results for model variables

\begin{tabular}{|l|c|c|c|c|}
\hline & $\begin{array}{c}\text { Swissness } \\
\text { Communication }\end{array}$ & $\begin{array}{c}\text { Brand } \\
\text { Commitment }\end{array}$ & Brand Trust & Brand Loyalty \\
\hline $\begin{array}{l}\text { Swissness } \\
\text { Communication }\end{array}$ & 0.68 & & & \\
\hline Brand Commitment & 0.57 & 0.80 & 0.61 & 0.66 \\
\hline Brand Trust & 0.58 & 0.64 & 0.72 & \\
\hline Brand Loyalty & 0.53 & 0.64 & & \\
\hline
\end{tabular}

Table 4: Fornell/Larcker test for model variables 


\begin{tabular}{|l|c|c|c|c|}
\hline \multicolumn{1}{|c|}{ Correlations } & $\begin{array}{c}\text { CMIN } \\
(\mathrm{df}=59) \\
\text { (unconstrained } \\
\text { model) }\end{array}$ & $\begin{array}{c}\text { CMIN } \\
(\mathrm{df}=60) \\
\text { (constrained } \\
\text { model) }\end{array}$ & $\begin{array}{c}\text { Chi-square- } \\
\text { difference }\end{array}$ & $\begin{array}{c}\text { Significance } \\
\text { level }\end{array}$ \\
\hline $\begin{array}{l}\text { Brand Commitment } \\
<->\text { Brand Trust }\end{array}$ & 413.9 & 634.9 & 221.0 & $0.1 \%$ \\
\hline $\begin{array}{l}\text { Brand Trust } \\
<->\text { Brand Loyalty }\end{array}$ & 413.9 & 727.5 & 313.6 & $0.1 \%$ \\
\hline
\end{tabular}

Table 5: Chi-square difference test

\subsection{Tests of Hypotheses}

To test $\mathrm{H} 1-\mathrm{H} 4$, we estimated the structural equation model (maximum likelihood) using Amos 7.0. The resulting measures suggest that the model fits the empirical data well $(\chi 2 / \mathrm{df}=9.79, \mathrm{CFI}=0.96, \mathrm{TLI}=0.95, \mathrm{RMSEA}=0.09, \mathrm{SRMR}=0.06)$. All of the structural paths are significant at the 0.001 level. Consequently, all hypotheses are supported. The $\mathrm{R}^{2}$ values range from 62.5 percent to 75.4 percent and are deemed acceptable (see Figure 2).

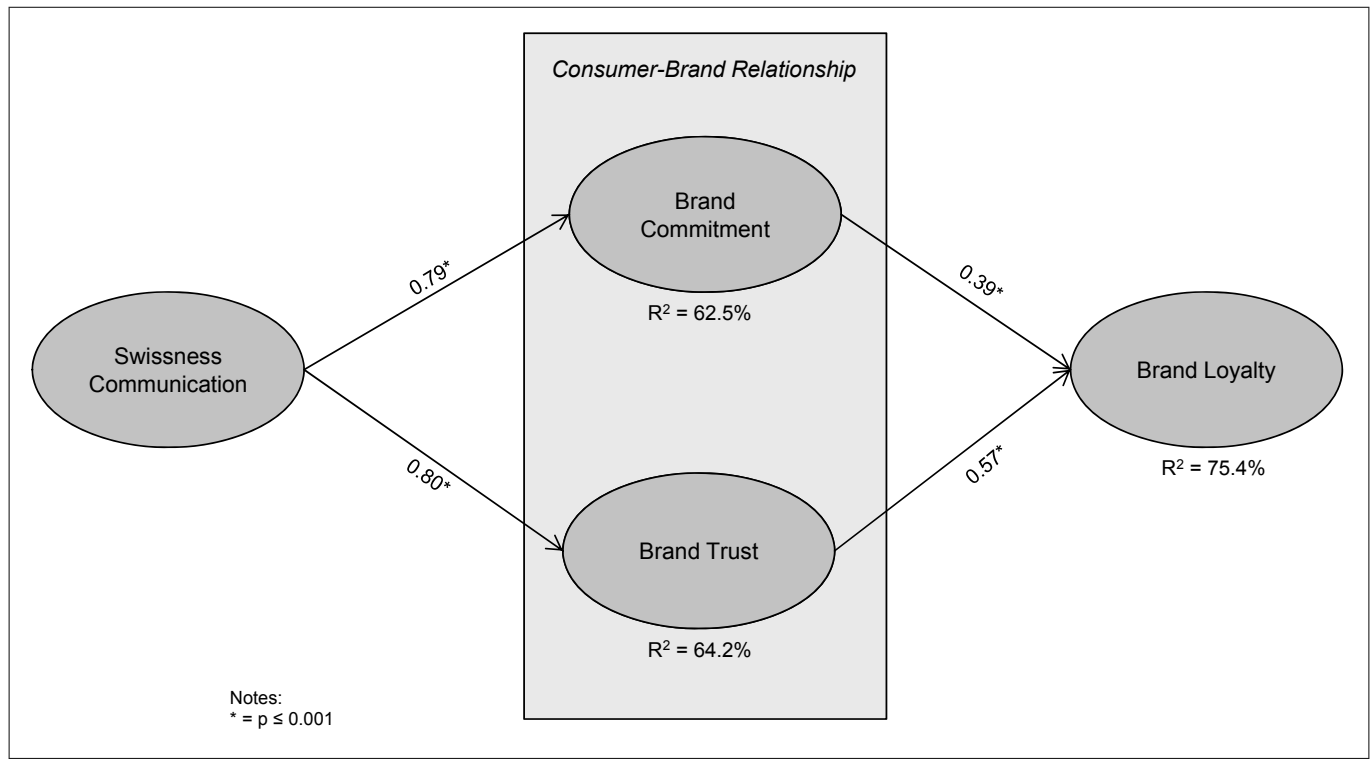

Figure 2: Results of the structural equation analysis

\section{Discussion, Implications and Future Research}

In view of an increasing internationalization of companies and growing competition, firms are more and more confronted with the challenge of attracting consumers to engage in long-term relationships with them. By transmitting a country-of-origin image to a brand, a psychological effect is triggered in the consumer's mind that favourably influences brand perception and brand behavior. The purpose of the present paper was to study the com- 
municated $\mathrm{COO}$ on consumer-brand relationships. In particular, this paper was driven by the question whether Swissness Communication affects brand commitment and brand trust.

As our study is the first one to examine Swissness Communication, it was necessary, in an initial step, to develop a measurement instrument. We started with a definition of Swissness Communication and defined the construct as being the perceived degree to which the Swiss origin of brands is communicated to consumers. Based on literature research and on interviews with German consumers, we generated different construct facets. The analysis revealed that Swissness Communication consists of three factors: high performance quality, exclusivity, and sympathy. After developing the measurement instrument, we tested our research model in a second step. Findings show that Swissness Communication strongly impacts brand commitment and brand trust. Hence, the communication of the Swiss origin of a brand has the potential to build consumer-brand relationships. Furthermore, Swissness Communication impacts - via brand commitment and brand trust brand loyalty, and thus, is indirectly linked to marketing advantages, such as an increased market share.

In addition to the aggregated analysis of our research model, we also tested the model for each of the four brands considered in our study separately. Due to page restrictions, we do not show the specific results here. However, we want to point out that the analysis of each sample leads to similar results. Hence, although we considered quite different brands (for example, we included product brands (Ricola and Swatch) as well service brands (Swiss International Airlines and Credit Suisse)), the findings are more or less the same. This strengthens the role of Swissness Communication as an antecedent of consumer-brand relationships.

While our study constitutes an important step toward an understanding of Swissness Communication and its effect on consumer-brand relationships, there are several limitations in our study. These issues are worthy of future research.

First, in the present study, the participants were of German origin. However, it is not known whether the findings also hold for consumers from other countries. For example, Switzerland has a more positive image in China and Russia, and a more negative image in Great Britain than it has in Germany (Feige et al. 2013). Hence, the results found in our study cannot be generalized, as they might depend on the national background of the people surveyed. Therefore, it is recommended that the model be tested using participants from other countries.

Second, with the measurement of Swissness Communication, a new scale has been developed. Although the scale has passed several reliability and validity tests, we tested the measurement on the basis of only one sample. Therefore, future studies are necessary in order to test the scale using other samples and, thereby, further validate it.

Third, we conducted the study using four brands from two different industries. In the present study, there were no differences between the brands and sectors concerning the models' results. However, this does not mean that the findings will be similar when considering other brands and other industries. Hence, to further generalize the findings, it is necessary to replicate the study across different brands and industries.

Fourth, in the present study, no attempt was made to investigate how consumer characteristics affect the relationships in the developed model. However, it can be assumed that the effect of Swissness Communication on consumer-brand relationships depends on mod- 
erating variables, such as the degree of 'consumer ethnocentrism' or 'brand involvement'. Future studies should explore these issues by introducing moderators into the investigation.

Fifth, we tested the model for the case of Switzerland. Testing the model beyond this specific case would enhance the generalizability of the observed effects. Furthermore, it would be interesting to extend the present model. Testing the impact of Swissness Communication on other variables that reflect strong consumer-brand relationships, such as brand passion or brand intimacy, might be useful, given the importance of these variables for brand success.

Finally, we have to admit that our study has focused on perceptual, non-observable constructs. By referring to theories and by building up hypotheses, we assumed causalities between the variables. Future studies should confirm these causalities using a longitudinal or a field experimental design (Hughes 2013). Furthermore, it would be valuable to go beyond the non-observable constructs, and add actual consumer behaviour in our model (e.g., share of wallet).

The present study has several managerial implications. The findings reveal that Swissness Communication is highly important for building consumer-brand relationships. Thus, managers of Swiss brands should consider the Swiss origin of the brand during the brand positioning process. In other words, managers are well advised to ensure that the typical characteristics of Switzerland and of Swiss products or services (these being high performance quality, exclusivity, and sympathy) are the main elements used in brand positioning. Based on this positioning, managers can develop brand communication strategies in order to stimulate customers' perceptions of the brand as being of Swiss origin. The Swissness Communication scale might be useful for this purpose. It is recommended that each construct dimension is addressed when planning activities to emphasize the Swiss origin of the brand. Hence, managers should communicate the high performance quality, exclusivity, and sympathy of Switzerland and its products and/or services. For example, managers could provide background information outlining the superior characteristics of a Swiss brand. This would be a way to increase the consumer's perception of the brand as being of high quality, and hence, to emphasize the brand's Swiss identity. Furthermore, managers could think about communications activities that enhance the perceived exclusivity of the brand: This could be achieved, for example, by introducing a luxurious product packaging for the product. Finally, companies should emphasize the sympathetic traits that Switzerland offers as a country of origin when communicating their brands. In conclusion, it has to be noted that a brand positioning does not usually only encompass COO elements. Additionally, there are consumers who are not influenced by COO-information (Herz/ Diamantopoulos 2013). In such a case, it might be advantageous to concentrate on only one dimension of the Swissness Communication construct when implementing communication activities. To ensure the perception of the Swiss origin of the brand, managers should engage in testing the influence of each construct dimension on brand commitment and brand trust. This would ensure that the focus is on the dimension with the strongest impact on these variables. In addition, this dimension should have the capacity to differentiate the brand from its competitors.

Much has been written about the COO topic over the past few decades. Our findings extend the results of these studies. The communicated COO not only influences cognitiverelated variables, such as product quality, but, at least in the case of Swissness Communi- 
cation, also affective-related variables, such as consumer-brand relationships. Further consideration of this topic could provide practitioners and academics with valuable insights into the specific impact of COO communication; in particular, the effect that communicated Swiss origin has on consumers of Swiss brands.

\section{References}

Albert, N./Merunka, D./Valette-Florence, P. (2013): Brand Passion: Antecedents and Consequences, in: Journal of Business Research, Vol. 66, No. 7, pp. 1062-1075.

Bagozzi, R.P./Edwards, J.R. (1998): A general approach for representing constructs in organizational research, in: Organizational Research Methods, Vol. 1, No. 1, pp. 45-87.

Bagozzi, R.P./Heatherton, T.F. (1994): A general approach to representing multifaceted personality constructs: Application to state self-esteem, in: Structural Equation Modeling, Vol. 1, No. 1, pp. 35-67.

Bagozzi, R.P./Yi, Y. (1988): On the Evaluation of Structural Equation Models, in: Journal of the Academy of Marketing Science, Vol. 16, No. 1, pp. 74-94.

Balabanis, G./Diamantopoulos, A. (2011): Gains and Losses from the Misperception of Brand Origin: The Role of Brand Strength and Country-of-Origin Image, in: Journal of International Marketing, Vol. 19, No. 2, pp. 95-116.

Bilkey, W.J./Nes, E. (1982): Country-of-Origin Effects on Product Evaluations, in: Journal of International Business Studies, Vol. 13, No. 1, pp. 89-99.

Brexendorf, T.O./Mühlmeier, S./Tomczak, T./Eisend, M. (2010): The impact of sales encounters on brand loyalty, in: Journal of Business Research, Vol. 63, No. 11, pp. 1148-1155.

Bruhn, M./Schwarz, J./Batt, V. (2012): Swissness als Erfolgsfaktor - Einsatz des Country-of-Origin zur Stärkung von Marken-Konsumenten-Beziehungen und der Markenbindung, in: Die Unternehmung, Jg. 66, Nr. 2, S. 153-179.

Casalo, L.V./Flavian, C./Guinaliu, M. (2008): Promoting Consumer's Participation in Virtual Brand Communities: A New Paradigm in Branding Strategy, in: Journal of Marketing Communications, Vol. 14, No. 1, pp. 19-36.

Chang, P.-L./Chieng, M.-H. (2006): Building Consumer-Brand Relationship: A Cross-Cultural Experiential View, in: Psychology \& Marketing, Vol. 23, No. 11, S. 927-959.

Chaudhuri, A./Holbrook, M.B. (2001): The Chain of Effects from Brand Trust and Brand Affect to Brand Performance: The Role of Brand Loyalty, in: Journal of Marketing, Vol. 10, No. 65, No. 2, pp. 81-93.

Chaudhuri, A./Holbrook, M.B. (2002): Product-class effects on brand commitment and brand outcomes: The role of brand trust and brand affect, in: Journal of Brand Management, Vol. 10, No. 1, pp. 33-58.

Cilingir, Z./Basfirinci, C. (2014): The Impact of Consumer Ethnocentrism, Product Involvement, and Product Knowledge on Country of Origin Effects: An Empirical Analysis on Turkish Consumers' Product Evaluation, in: Journal of International Consumer Marketing, Vol. 26, No. 4, pp. 284-310.

Cordell, V.V. (1992): Effects of Consumer Preferences for Foreign Sourced Products, in: Journal of International Business Studies, Vol. 23, No. 2, pp. 251-269.

Delgado-Ballester, E./Munuera-Alemán, J.L. (2001): Brand Trust in the Context of Consumer Loyalty, in: European Journal of Marketing, Vol. 35, No. 11/12, pp. 1238-1258. 
Delgado-Ballester, E./Munuera-Alemán, J.L./Yagüe-Guillén, M.J. (2003): Development and Validation of a Brand Trust Scale, in: International Journal of Market Research, Vol. 45, No. 1, pp. 35-53.

Dutton, J.E./Dukerich, J.M./Harquail, C.V. (1994): Organizational Images and Member Identification, in: Administrative Science Quarterly, Vol. 39, No. 2, pp. 239-263.

Escalas J.E./Bettman, J.R. (2003): You are what they eat: the influence of reference groups on consumers' connections to brands, in: Journal of Consumer Psychology, Vol. 13, No. 3, pp. 339-348.

Feige, S./Fischer, P.M./von Matt, D./Reinecke, S. (2013): Swissness Worldwide 2013 - Image und internationaler Mehrwert der Marke Schweiz, St. Gallen.

Fornell, C./Larcker, D.F. (1981): Evaluating Structural Equation Models with Unobservable Variables and Measurement Error, in: Journal of Marketing Research, Vol. 18, No. 1, pp. 39-50.

Gürhan-Canli, Z./Maheswaran, D. (2000): Determinants of Country-of-Origin Evaluations, in: Journal of Consumer Research, Vol. 27, No. 1, pp. 96-108.

Hastak, M./Hong, S.-T. (1991): Country-of-Origin Effects on Product Quality Judgments: An Information Integration Perspective, in: Psychology \& Marketing, Vol. 8, No. 2, pp. 129-143.

Hong, S.-T./Kang, D.K. (2006): Country-of-Origin Influences on Product Evaluations: The Impact of Animosity and Perceptions of Industriousness Brutality on Judgments of Typical and Atypical Products, in: Journal of Consumer Psychology, Vol. 16, No. 3, pp. 232-239.

Jiménez, N.H./San Martín, S. (2010): The Role of Country-of-Origin, Ethnocentrism and Animosity in Promoting Consumer Trust. The Moderating Role of Familiarity, in: International Business Review, Vol. 19, No. 1, pp. 34-45.

Kressmann, F./Sirgy, J.M./Hermann, A./Huber, F./Huber, S./Lee, D.-J. (2006): Direct and indirect effects of self-image congruence on brand loyalty, in: Journal of Business Research, Vol. 59, No. 9, pp. 955-964.

Kühn, R./Weiss, M. (1998): Das "Made-in“-Image der Schweiz im internationalen Vergleich, in: Die Unternehmung, Jg. 52, Nr. 1, S. 49-60.

Lee, K.L./Lee, B.-K./Lee, W.-N. (2013): Country-of-origin fit's effect on consumer product evaluation in cross-border strategic brand alliance, in: Journal of Business Research, Vol. 66, No. 3, pp. 354-363.

Lee, J.K./Lee, W.-N. (2009): Country-of-Origin Effects on Consumer Product Evaluation and Purchase Intention: The Role of Objective versus Subjective Knowledge, in: Journal of International Consumer Marketing, Vol. 21, No. 2, pp. 137-151.

Li, W.-K./Wyer Jr., R.S. (1994): The Role of Country of Origin in Product Evaluations: Informational and Standard-of-Comparison Effects, in: Journal of Consumer Psychology, Vol. 3, No. 2, pp. 187-212.

Maheswaran, D./Chen, C.Y. (2006): Nation Equity: Incidental Emotions in Country-of-Origin Effects, in: Journal of Consumer Research, Vol. 33, No. 3, pp. 370-376.

Mazodier, M./Merunka, D. (2012): Achieving brand loyalty through sponsorship: The role of fit and self-congruity, in: Journal of the Academy of Marketing Science, Vol. 40, No. 6, pp. 807-820.

Morgan, R.M./Hunt, S.D. (1994): The Commitment-Trust Theory of Relationship Marketing, in: Journal of Marketing, Vol. 58, No. 3, pp. 20-38.

Nunnally, J.C./Bernstein, I.H. (1994): Psychometric Theory, New York.

Oliver, R.L. (1999): Whence Consumer Loyalty?, in: Journal of Marketing, Vol. 63, Special Issue, pp. 33-44. 
Parameswaran, R./Pisharodi, R.M. (1994): Facets of Country of Origin Image: An Empirical Assessment, in: Journal of Advertising, Vol. 23, No. 1, pp. 43-56.

Piron, F. (2000): Consumers' perceptions of the country-of-origin effect on purchasing intention of (in)conspicuous products, in: Journal of Consumer Marketing, Vol. 17, No. 4, pp. 308-321.

Quester, P.G./Smart, J. (1998): The influence of consumption situation and product involvement over consumers' use of product attribute, in: Journal of Consumer Marketing, Vol. 15, No. 3, pp. 220-238.

Schooler, R.D. (1965): Product Bias in the Central American Common Market, in: Journal of Marketing Research, Vol. 2, No. 4, pp. 394-397.

Sirgy, M.J./Johar, J.S./Coskun Samli, A./Claiborne, C.B. (1991): Self-congruity versus functional congruity: Predictors of consumer behaviour, in: Journal of the Academy of Marketing Science, Vol. 19, No. 4, pp. 363-375.

Smit, E./Bronner, F./Tolboom, M. (2007): Brand Relationship Quality and Its Value for Personal Contact, in: Journal of Business Research, Vol. 60, No. 6, S. 627-633.

Spence, M. (1973): Job marketing signalling, in: Quarterly Journal of Economics, Vol. 87, No. 3, pp. 355-374.

Swaminathan, V./Page, K.L./Gürhan-Canli, Z. (2007): "My" Brand or “Our” Brand: The Effects of Brand Relationship Dimensions and Self-Construal on Brand Evaluations, in: Journal of Consumer Research, Vol. 34, No. 2, pp. 248-259.

Tajfel, H./Turner, J.C. (1985): The social identity theory of intergroup behavior, in: Worchel, S./ Austin, W.G. (eds.): Psychology of Intergroup Relations, Vol. 2, pp. 7-24.

Thorelli, H.B./Lim, J./Ye, J. (1989): Relative Importance of Country of Origin, Warranty and Retail Store Image on Product Evaluations, in: International Marketing Review, Vol. 6, No. 1, pp. $35-46$.

Tuskej, U./Golob, U./Podnar, K. (2013): The role of consumer-brand identification in building brand relationships, in: Journal of Business Research, Vol. 66, No. 1, pp. 53-59.

Unahanandh, S./Assarut, N. (2014): Dairy Products Market Segmentation: The Effects of Country of Origin on Price Premium and Purchase Intention, in: Journal of International Food \& Agribusiness Marketing, Vol. 25, No. 2, pp. 122-133.

Usunier, J.-C./Cestre, G. (2007): Product Ethnicity: Revisiting the Match Between Products and Countries, in: Journal of International Marketing, Vol. 15, No. 3, pp. 32-72.

Veale, R./Quester, P. (2009): Do Consumer Expectations Match Experience? Predicting the Influence of Price and Country of Origin on Perceptions of Product Quality, in: International Business Review, Vol. 18, No. 2, pp. 134-144.

Verlegh, P.W.J./Steenkamp, J.E.M. (1999): A review and meta-analysis of country-of-origin research, in: Journal of Economic Psychology, Vol. 20, No. 5, pp. 521-546.

Verlegh, P.W.J./Steenkamp, J.E.M./Meulenberg, M.T.G. (2005): Country-of-origin effects in consumer processing of advertising claims, in: International Journal of Research in Marketing, Vol. 22, No. 2, pp. 127-139.

Walter, A./Müller, T.A./Helert, G./Ritter, T. (2003): Functions of industrial supplier relationships and their impact on relationship quality, in: Industrial Marketing Management, Vol. 32, No. 2, pp. 159-169. 
Manfred Bruhn, Prof. Dr., ist Inhaber des Lehrstuhls für Marketing und Unternehmensführung an der Wirtschaftswissenschaftlichen Fakultät der Universität Basel und Honorarprofessor an der Technischen Universität München.

Verena Batt, Dr. rer. pol., ist Postdoctoral Researcher am Lehrstuhl für Marketing und Unternehmensführung an der Wirtschaftswissenschaftlichen Fakultät der Universität Basel.

Anschrift: Universität Basel, Wirtschaftswissenschaftliche Fakultät, Lehrstuhl für Marketing und Unternehmensführung, Peter Merian-Weg 6, 4002 Basel 